\title{
Upper Paleocene radiolarians from DSDP Sites 549 and 550, Goban Spur, NE Atlantic
}

3

Jun Liu*, Jonathan C. Aitchison, Jason R. Ali

Department of Earth Sciences, The University of Hong Kong, Pokfulam Road, Hong Kong SAR, China

*Corresponding author

Email address: junliu@hku.hk; Phone (office): (+852) 22415109

\section{Abstract}

Upper Paleocene-lower Eocene sequences of mainly pelagic sediments in DSDP Sites 549 and 550 of Goban Spur, NE Atlantic, representing time periods of 10 and 6 m.y. respectively, were examined to investigate the biotic response of radiolarians to the PETM. The preservation of radiolarians in the lower Eocene sequences for both sites is poor. Upper Paleocene radiolarian assemblages, representing a time interval of 59-56 Ma at Site 549 and a much shorter period at Site 550, are generally moderately well-preserved. Fifty four species were identified. Four species occur significantly earlier in the middle high latitude NE Atlantic than in New Zealand, where the sudden appearance during the PETM has been taken as evidence of global pole-ward migration of warm-water radiolarians. Available model shows that the Goban Spur area should belong to the subpolar surface ocean gyre in the early Paleogene. Thus, our investigation questions the validity of the previously used index species of subtropical warm water masses. High-latitude offshore sections across the $\mathrm{P} / \mathrm{E}$ boundary with well preserved radiolarians are needed to test the hypothesis of pole-ward migration of warm-water radiolarians during this geologically transient global warming period.

Keywords: Upper Paleocene; radiolarians; NE Atlantic; biotic response; PETM 


\section{Introduction}

Biotic responses to the Paleocene - Eocene thermal maximum (PETM) have been extensively studied (e.g., Aubry et al., 1998; Wing et al., 2003) since the associated CIE (Carbon Isotope Excursion) and PETM were first identified in the southern ocean ODP Site 690 (Kennett and Stott, 1991). Radiolarians, the skeletons of which are composed of pure amorphous opaline silica, are extremely diverse and widely distributed marine plankton with a long geologic

Subsequently, radiolarian assemblages in a well-constrained P/E boundary section from western North Atlantic ODP Hole 1051A were reported (Sanfilippo and Blome, 2001). This section contains the only known record of a well-preserved PETM radiolarian assemblage in the deep-sea. The results show that there is no obvious change in radiolarian composition (number of first and last occurrences of radiolarian taxa) across the PETM interval and only two first occurrences of radiolarian taxa (Podocyrtis papalis and Phormocyrtis turgida) were identified in the interval of the PETM (Sanfilippo and Blome, 2001).

A recent study provides the only quantitative investigation of radiolarians across the $P / E$ boundary using samples from an onshore section in New Zealand (Hollis, 2006). This section is also the only one that shows a significant faunal change during the PETM with the first occurrences of 13 species in the PETM interval between $157 \mathrm{~m}$ and $160.9 \mathrm{~m}$ above the K/T boundary (Hollis, 2006; Hollis et al., 2005). The last occurrences of three species in this interval suggest that the faunal turnover is not an artifact of stratigraphic discontinuity (Hollis, 2006). Based on the abrupt appearance of five so-called typical low-latitude species, a pole-ward migration of warm-water radiolarians during the PETM was suggested (Hollis, 2006).

During Deep Sea Drilling Project (DSDP) Leg 80, four sites were drilled on the Goban Spur in the NE Atlantic (Fig. 1). The main objective of this leg was to investigate the development of 
the continental margin of Western Europe (de Graciansky et al., 1985). Sites 549 and 550 drilled an expanded sequence within Chron C24r that contains part of the PETM interval and records a number of events related to it. Hence, abundant research has been conducted using materials from these sites (e.g., Ali and Hailwood, 1998; Kahn and Aubry, 2004; Knox et al., 1996; Thomas and Bralower, 2005). However, early Paleogene radiolarians from these sites have not been studied until now.

In order to investigate the biotic response of radiolarians to the PETM, we examined samples across the P/E boundary from these two sites ( 59-49 Ma for Site 549 and 57-51 Ma for Site 550). Unfortunately, the results are disappointing in that the preservation of radiolarians is very variable. The radiolarian assemblages above and just below the PETM are so poor that their identification is almost impossible. However, we have found that the upper Paleocene radiolarians are generally well-preserved and several so-called warm-water species used by Hollis (2006) to indicate a pole-ward migration of radiolarians during the PETM occurred significantly earlier in the NE Atlantic than in New Zealand. Thus, the main objectives of this study are to document late Paleocene radiolarian faunas and events from Leg 80 and discuss the implications of the significantly earlier occurrence of these so-called warm-water species in the NE Atlantic compared to New Zealand.

\section{Materials and methods}

\subsection{Sample preparation}

This study is based on the paleomagnetic samples used in the study by Ali and Hailwood (1998). Sixty-four samples from DSDP Site 549 between 274.91 mbsf (meters below sea floor) and 381.12 mbsf including the well-constrained P/E boundary and 17 samples from Site 550 between $328.38 \mathrm{mbsf}$ and $424.98 \mathrm{mbsf}$ were processed. For the extraction of radiolarians, the techniques used differ slightly from the traditional method for soft marine sediments introduced by Sanfilippo et al. (1985). Each sample was first put into a $400 \mathrm{~cm}^{3}$ beaker with about $200 \mathrm{ml}$ of a solution of $10 \%$ hydrogen peroxide and in which about $5 \mathrm{~g}$ sodium pyrophosphate had been dissolved to remove organic materials and disaggregate the sediment. It was then sieved at $400 \mu \mathrm{m}$ (if lumps remained, the above procedure was repeated), $180 \mu \mathrm{m}$ (if radiolarians were abundant) and $63 \mu \mathrm{m}$. Several drops of dilute hydrochloric acid were then put into the residue to remove the calcareous component and it was again sieved at $63 \mu \mathrm{m}$. Finally, the cleaned residue was placed in an oven to dry at about $50^{\circ} \mathrm{C}$ and then transferred into a plastic bottle for storage.

The cleaned residue was mounted using Norland Optical Adhesive and covered with a $22 \times$ $38 \mathrm{~mm}$ cover slip. All radiolarians were counted for samples for which only one slide can be prepared. For richer samples, two slides were prepared and examined. To save time, the following double count method was used. About one thousand specimens were first counted. The remainder was then searched for rare species. Selected specimens were mounted on SEM stubs using a thin brush under a binocular microscope, and then coated with gold. Digital images were captured using a SEM. 
The total abundance of radiolarians in each sample was roughly estimated based on the weight of siliceous residue: A (abundant, > $0.1 \mathrm{~g}$ ), C (common, $0.01-0.1 \mathrm{~g}$ ), F (few, < $0.01 \mathrm{~g}$ ), $B$ (barren). The following abbreviations are used for species abundance and preservation: $A$ $=$ abundant $(>50$ individuals for each species), $C=$ common $(5-50)$ and $F=$ few (< five); and $\mathrm{W}=\operatorname{good}($ minor dissolution), $\mathrm{M}=$ moderate (apparent dissolution with possible identification), $\mathrm{P}=$ poor (identification impossible), and $\mathrm{S}=$ silicified.

\subsection{Age model}

The age model for Sites 549 and 550 is based on published biostratigraphic and geomagnetic data (Table 1). Numerical ages assigned to these events were derived from GTS2004 (Gradstein et al., 2005). Linear sedimentation rates were assumed between datum ages.

\section{Hiatuses, lithology, and siliceous fossil occurrences}

\subsection{Site 549}

Two holes (549A and 549) were drilled at Site 549 with a water depth of about $2533 \mathrm{~m}$. Lithology at this site has been divided into 11 units (de Graciansky et al., 1985). Our sampled cores belong to lithologic units 2 and 3 of Hole 549 (Table 2).

Samples 549-10-1-41 to -10-3-60 were collected from lithologic unit 2 that mainly consists of nannofossil chalks. Abundant poorly preserved siliceous fossils were extracted from these samples except for sample 549-10-1-41 that generated some moderately preserved radiolarians. Samples 549-10-4-30 to -14-6-86 belong to subunit 3a, which is composed of marly nannofossil chalks in which no siliceous fossils were previously reported (de Graciansky et al., 1985). Siliceous fossils were successfully extracted from samples 549-10-4-30 to -11-2-19 and from 549-13-2-71 to -13-6-107, but the very poor preservation of these samples makes identification impossible. Samples 549-15-1-119 to -16-3-11 belong to subunit $3 \mathrm{~b}$ that consists of nannofossil chalks. No siliceous fossils were extracted from these samples.

A short hiatus between subunits $3 \mathrm{~b}$ and $3 \mathrm{c}$ removed the topmost part of the CIE recovery (Thomas and Bralower, 2005) based on the orbitally-tuned age model for ODP Site 690 (Röhl et al., 2000). The top of the PETM at Site 549 is located between 335.16 mbsf and 335.55 mbsf corresponding to the lowest occurrence of nannofossil Tribrachiatus contortus (morphotype B) and the highest occurrence of Fasciculithus tympaniformis respectively (Aubry et al., 1996) if we follow the orbital age model. The base of the CIE that has been taken as the P/E boundary and assigned a numerical age of 55.8 Ma (Gradstein et al., 2005) is located at $339.68 \mathrm{mbsf}$ at Site 549 (Thomas and Bralower, 2005). Thus our samples 549-16-4-36 and 549-16-5-35 are located between the onset of the CIE and top of the PETM and consequently, become the most important samples to examine if there are so-called excursion taxa or a sudden acme of a certain group such as those that have been reported in several other marine planktonic protozoans including siliceous diatoms (Sluijs et al., 2007). Unfortunately, preservation of siliceous fossils in these two samples is very poor and identification of radiolarian taxa is thus impossible. 
Samples 549-16-6-83 to -17-6-138 belong to subunit 3c that is composed of siliceous marly nannofossil chalks. Except for those silicified samples, radiolarians are generally well preserved and abundant in this subunit. Samples 549-17-7-7 to -21-2-62 belong to subunit $3 d$ that is composed of siliceous nannofossil chalks. Radiolarian fossils are generally abundant and well preserved between samples -17-7-7 and -19-2-46 except for those samples that are silicified. However, the preservation deteriorates downhole.

The details of preservation and occurrence of radiolarians of Site 549 are listed in Table 2. The stratigraphic ranges of radiolarian species of this site are presented in Fig. 2.

\subsection{Site $\mathbf{5 5 0}$}

Two holes were drilled at Site 550, the deepest site of the Goban Spur transect with a water depth of $4432 \mathrm{~m}$. Hole 550 contains a thick section of upper Paleocene-lower Eocene marly nannofossil chalk (lithological subunit 2a) and siliceous marly nannofossil chalk and mudstone (lithological subunit 2b). A short hiatus exists between subunits $2 \mathrm{a}$ and $2 \mathrm{~b}$. Siliceous fossils are generally sparse in the processed samples of Subunit $2 a$ and no identifiable radiolarians are extracted from these samples. Four samples belong to the Subunit $2 \mathrm{~b}$ were processed, of which three samples contain identifiable radiolarians. The details of preservation and occurrence of radiolarians of Site 550 are listed in Table 3.

\section{Did a pole-ward migration of warm-water radiolarians occur during the PETM?}

Based on the abrupt appearance of five species in a New Zealand section including Amphicraspedum murrayanum, A. prolixum s.s., Bekoma bidartensis, Lychnocanium auxilla (Lychnocanoma auxilla in our paper), and Phormocyrtis cubensis that were taken as subtropical index species with upper Paleocene FOs at low latitudes, Hollis (2006) concluded that global warming during the PETM promoted pole-ward migration of warm-water radiolarians. This opinion was also adopted by a comprehensive review paper on the PETM (Sluijs et al., 2007). Our investigation at the Goban Spur area, however, questions the validity of these species as index species of tropical-subtropical warm currents.

Except for Phormocyrtis cubensis that is not present in our samples, four of these five species taken as typical low-latitude warm water species (Hollis, 2006) show significantly earlier FOs in Site 549 compared with the New Zealand section (Fig. 2; Table 2). During the late Paleocene, Goban Spur was located at similar latitude to Mead Stream (Fig. 3). Modeled result (Huber et al., 2004) shows that both the Goban Spur and the Mead Stream should belong to the subpolar surface ocean gyres in the early Paleogene times. Although there is no direct proxy data of temperature from NE Atlantic and New Zealand in late Paleocene, available proxy data from Bighorn Basin (Paleolatitude $\sim 45^{\circ} \mathrm{N}$, Wing et al., 2000), Arctic regions (Slujis et al., 2006; Tripati et al., 2001; Weijers et al., 2007), and SW Pacific (Bijl et al., 2009) suggest that NE Atlantic is probably not warmer than New Zealand during the late Paleocene. Thus, the occurrence of these four species at the Goban Spur during the late Paleocene indicates that they were probably more cosmopolitan rather than limited to the warm subtropical ocean gyres. 
In addition, the PETM is a geologically transient period, which only lasted $\sim 170,000$ years (Röhl et al., 2007). If Hollis's (2006) hypothesis that typical warm water radiolarians migrated into the New Zealand region with the expansion of the subtropical warm pool during the PETM is right, these species should disappear from Mead Stream after the PETM as is observed in dynocyst Apectodinium, a typical subtropical dinoflagellate whose occurrence in high latitudes is limited to the duration of the PETM (e.g., Sluijs et al., 2006). However, except for Amphicraspedum murrayanum which only existed during the PETM at Mead Stream, four of these five species extended above the PETM (Hollis, 2006).

On the other hand, we notice that radiolarians are more poorly preserved in the upper Paleocene at Mead Stream in New Zealand compared with those associated with Eocene strata (Hollis, 2006). Thus, an alternative explanation should be considered, i.e. that the abrupt appearance of these so-called warm-water species is an artifact of severe diagenesis and/or dissolution below the CIE base compared with the section above the CIE base.

Although we doubt the validity of Hollis' subtropical index fossils, we are not saying that an expansion of subtropical warm pool and consequently, a pole-ward migration of warm water radiolarians is impossible during the PETM. To test this hypothesis, however, we need more knowledge about the biogeographic distribution of radiolarians around the P/E boundary, especially from high latitude sites with well preserved radiolarians.

\section{Conclusion}

Well preserved radiolarians were extracted from the upper Paleocene at DSDP Sites 549 and 550. They permit sufficient identification and provide important data, which will help fill an informational gap in the radiolarian distribution at middle high latitudes in the North Atlantic. Radiolarian preservation is discontinuous throughout the upper Paleocene-lower Eocene and preservation is generally poor in other sections. Four out of five species taken as typical warm water indicators by Hollis (2006) have significantly earlier FOs at Goban Spur compared with Mead Stream leading us to suggest that the abrupt appearances of these species at Mead Stream are likely an artifact caused by severe diagenesis and/or dissolution. The hypothesis of a pole-ward migration of warm water radiolarians during the PETM remains premature at present and needs to be tested by sampling of high latitude sites that across the PETM with well preserved radiolarians.

\section{Species list}

Reference to the author, the first definition, the first illustration, the currently adopted species concept and consulted illustration are given. Species listed here are in alphabetical order. All illustrated specimens are deposited at Department of Earth Sciences, The University of Hong Kong and can be located with SEM stub number, followed by specimen number on the stub.

\section{Amphicraspedum murrayanum Haeckel}

Plate 1 , figures 3,4 
Amphicraspedum murrayanum Haeckel, 1887, p. 523, pl. 44, fig. 10; Sanfilippo and Riedel, 1973, p. 524, pl. 10, figs. 3-6; pl. 28, fig. 1; Nishimura, 1987, pl.1, figs. 14, 18; Sanfilippo and Blome, 2001, p. 208, fig. 8a; Hollis, 2006, pl. 1, figs. 18, 19; Jackett et al., 2008, pl. 4, figs. 1, 2.

\section{Amphicraspedum prolixum Sanfilippo and Riedel group}

Plate 1, figures 32, 33

Amphicraspedum prolixum Sanfilippo and Riedel group, 1973, p. 524, pl. 10, figs. 7-11; pl. 28, figs. 3, 4; Hollis, 2006, pl. 1, figs. 14, 20, 21; Jackett et al., 2008, pl. 4, figs. 3-5.

\section{Amphisphaera coronata (Ehrenberg)}

Plate 1, figure 7

Stylosphaera coronata Ehrenberg, 1873, p. 258; 1875, pl. 25, fig. 4.

Stylosphaera coronata coronata Ehrenberg, Sanfilippo and Riedel, 1973, p. 520, pl. 1, figs. 13-17; pl. 25, fig. 4; Nishimura, 1992, pl. 1, fig. 2; pl. 11, fig. 9. Jackett et al., 2008, pl. 3, fig. 10.

Amphisphaera coronata (Ehrenberg), Hollis, 1997, p. 35, pl. 2, figs. 14-17.

\section{Amphisphaera goruna (Sanfilippo and Riedel)}

Plate 1, figure 9

Stylosphaera goruna Sanfilippo and Riedel, 1973, p. 521, pl. 1, figs. 20-22; pl. 25, figs. 9, 10; Nishimura, 1987, pl. 1, fig. 3.

Amphisphaera goruna (Sanfilippo and Riedel), Hollis, 1997, p. 34, pl. 2, figs. 10, 11.

\section{Amphisphaera macrosphaera (Nishimura)}

Plate 1, figure 8

Stylosphaera coronata macrosphaera Nishimura, 1992, p. 325, pl. 1, figs. 3, 4; pl. 11, fig. 1. Amphisphaera macrosphaera (Nishimura), Hollis, 1997, p. 34, pl. 2, figs. 12, 13.

\section{Axoprunum pierinae (Clark and Campbell)}

Plate 1 , figures 1,2

Lithatractus pierinae Clark and Campbell, 1942, p. 34, pl. 5, fig. 25.

Axoprunum pierinae (Clark and Campbell) group, Sanfilippo and Riedel, 1973, p. 488, pl. 1, figs. 6-12; pl. 23, fig. 3; Nishimura, 1987, pl. 1, fig. 6.

\section{Bathropyramis magnifica (Clark and Campbell)}

Plate 2, figure 11

Sethopyramis magnifica Clark and Campbell, 1942, p. 72, pl. 8, figs. 1, 5, 9.

Bathropyramis magnifica (Clark and Campbell), Jackett et al., 2008, pl. 1, fig. 16.

\section{Bekoma bidartensis Riedel and Sanfilippo}

Plate 2, figure 32

Bekoma bidartensis Riedel and Sanfilippo, 1971, p. 1592, pl. 7, figs. 1, 2, 5, 7; Foreman, 1973, p. 432, pl. 3, figs. 20, 21; pl. 10, fig. 6; Nishimura, 1992, pl. 5, figs. 8, 9; Jackett et al., 2008, pl. 1, fig. 12. 


\section{Buryella pentadica Foreman}

Plate 2, figure 12

4

Buryella pentadica Foreman, 1973, p. 433, pl. 8, fig. 8; pl. 9, figs. 15, 16; Nishimura, 1987, pl.

2 , fig. 9.

6

\section{Buryella tetradica tetradica Foreman}

Plate 2, figure 13

Buryella tetradica Foreman, 1973, p. 433, pl. 8, figs. 4, 5; pl. 9, figs. 13, 14; Nishimura, 1987, pl. 2, fig. 8; Jackett et al., 2008, pl. 2, fig. 20.

Buryella tetradica tetradica Foreman, Hollis, 2002, p. 300, pl. 4, figs, 13, 14.

\section{Buryella tetradica tridica O'Connor}

Buryella tridica O'Connor, 2001, p. 11, pl. 2, figs. 9a-15; pl. 4, figs. 14-25.

Buryella tridica O'Connor, Hollis, 2002, p. 300, pl. 4, fig. 12.

Remarks: The discovery of this variant of Buryella tetradica in North Atlantic expands its geographical distribution which has previously been suggested as a possible geographically restricted morphotype in South Pacific by Hollis (2002).

\section{Carposphaera subbotinae (Borisenko)}

\section{Cassideus mariae Nishimura}

Plate 1, figure 49; plate 2, figures 1-3

Cassideus mariae Nishimura, 1992, p. 333, pl. 4, figs. 1-3.

\section{Clathrocycloma? catherinea Nishimura}

Clathrocycloma? catherinea Nishimura, 1992, p. 334, pl. 4, figs. 10, 11.

\section{Cornutella californica Campbell and Clark}

Cornutella californica Campbell and Clark, 1944, p. 22, pl. 7, figs. 33, 34, 42, 43; Hollis, 1997, p. 71 , pl. 17, figs. $13-15 ; 2002$, pl. 6, figs. $4,5$.

\section{Cromyomma riedeli Nishimura}

Cromyomma riedeli Nishimura, 1992, p. 322, pl. 1, figs. 6, 7; pl. 11, fig. 7

\section{Dendrospyris golli Nishimura}

Plate 2, figures 33, 34

Dendrospyris golli Nishimura, 1992, p. 330, pl. 3, figs. 1, 2; pl. 12, fig. 11.

Dictyocephalus middouri s.l. Nishimura 
Plate 2, figures 18-20

Dictyocephalus middouri Nishimura, 1992, p. 336, pl. 9, figs. 10-12.

Remarks: specimens examined here include those with three-bladed apical horn.

\section{Dictyophimus? sp. aff. Pterocodon campana Ehrenberg}

Pterocodon campana Ehrenberg, 1873, p. 255; 1875, p. 82, pl. 19, fig. 1.

Dictyophimus? sp. aff. Pterocodon campana Ehrenberg, Nishimura, 1992, pl. 10, fig. 15.

\section{Diplocyclas pseudobicorona pseudobicorona Nishimura}

Plate 2, figures 6-10

Diplocyclas pseudobicorona pseudobicorona Nishimura, 1992, p. 340, pl. 4, figs. 4-6; pl. 13, fig. 14.

\section{Diplocyclas pseudobicorona teres Nishimura}

Plate 2, figures 4, 5

Diplocyclas pseudobicorona teres Nishimura, 1992, p. 340, pl. 4, figs. 8, 9; pl. 13, fig. 20.

\section{Diploplegma? sp. aff. D. somphum Sanfilippo and Riedel}

Diploplegma somphum Sanfilippo and Riedel, 1973, p. 491, pl. 4, fig. 5.

Diploplegma? sp. aff. D. somphum Sanfilippo and Riedel, Nishimura, 1992, p. 324, pl. 2, figs. 6, 10; pl. 11, fig. 10.

\section{Dorcadospyris platyacantha (Ehrenberg) group}

Plate 2, figures 35, 36

Peralospyris platyacantha Ehrenberg 1873, p. 247; 1875, pl.22, fig. 8.

Dorcadospyris platyacantha (Ehrenberg), Sanfilippo and Riedel, 1973, p. 528, pl. 17, figs. 11-15; pl. 33, fig. 2; Nishimura, 1992, pl. 3, figs. 3, 4; Jackett et al., 2008, pl. 4, fig. 17.

\section{Hexacontium palaeocenicum Sanfilippo and Riedel}

Plate 1, figures 15-18

Hexacontium palaeocenicum Sanfilippo and Riedel, 1973, p. 492, pl. 4, fig. 2; pl. 24, fig. 4;

Nishimura, 1987, pl. 1, figs. 8, 11; Jackett et al., 2008, pl. 3, fig. 5.

\section{Hexacontium sp.}

Plate 1, figures 19-21

Remarks: This form is different from Hexacontium palaeocenicum with seven external spines.

\section{Lamptonium pennatum Foreman}

Plate 2, figures 30, 31

Lamptonium pennatum Foreman, 1973, p. 436, pl. 6, figs. 3-5; pl. 11, fig. 13; Jackett et al., 2008, pl. 1, fig. 10.

Lithelius foremanae Sanfilippo and Riedel 
Lithelius foremanae Sanfilippo and Riedel, 1973, p. 522, pl. 7, figs. 1-6; pl. 26, figs. 4, 5;

Jackett et al., 2008, pl. 4, fig. 20.

\section{Lithomespilus coronatus Squinabol}

Plate 1, figures 10-14

Lithomespilus coronatus Squinabol, 1904, p. 198, pl. 4, fig. 7; Hollis, 1997, p. 37, pl. 4, figs. 1-3.

\section{Lychnocanium carinatum Ehrenberg}

Plate 2, figures 21-22

Lychnocanium carinatum Ehrenberg, 1875, p. 78, pl. 8, fig. 5; Nishimura, 1987, pl. 3, figs. 6, 11; Jackett et al., 2008, pl. 1, fig. 25.

\section{Lychnocanoma anacolum Foreman}

Lychnocanoma anacolum Foreman, 1973, p. 437, pl. 1, fig. 19; pl. 11, fig. 7; Jackett et al., 2008, pl. 1, fig. 24.

\section{Lychnocanoma auxilla Foreman}

Plate 2, figures 23-29

Lychnocanoma auxilla Foreman, 1973, p. 437, pl. 2, fig. 6; pl. 11, figs. 1, 2; Jackett et al., 2008, pl. 1, fig. 20.

\section{Lychnocanoma babylonis (Clark and Campbell) group}

Dictyophimus babylonis Clark and Campbell, 1942, p. 67, pl. 9, figs. 32, 36.

Sethochytris babylonis (Clark and Campbell) group, Riedel and Sanfilippo, 1970, p. 528, pl. 9, figs. 1-3.

Lychnocanoma babylonis (Clark and Campbell) group, Foreman, 1973, p. 437, pl. 2, fig. 1. Lychnocanoma sp. aff. L. babylonis (Clark and Campbell), Nishimura, 1987, pl. 3, figs. 3-5.

\section{Phormocyrtis striata exquisita (Kozlova)}

Plate 2, figures 15-16

Podocyrtis exquisita Kozlova, in Kozlova and Gorbovetz, 1966, p. 106, pl. 17, fig. 2. Phormocyrtis striata exquisita (Kozlova), Foreman, 1973, p. 438, pl. 7, figs. 1-4, 7, 8; pl. 12, fig. 5; Nishimura, 1987, pl. 2, fig. 13; 1992, pl. 9, figs. 4, 5; Jackett et al., 2008, pl. 1, fig. 18.

\section{Podocyrtis sp. aff. P. papalis Ehrenberg}

Plate 2, figure 14

Podocyrtis papalis Ehrenberg, 1847, p. 55, fig. 2.

Podocyrtis sp. aff. P. papalis Ehrenberg, Nishimura, 1992, pl. 10, figs. 1-3; pl. 13, fig. 18.

\section{Prunopyle adelstoma Kozlova}

Plate 1, figure 37

Prunopyle adelstoma Kozlova, in Kozlova and Gorbovetz, 1966, p. 67, pl. 10, figs. 3, 4; Hollis, 2002, p. 289, pl. 2, figs. 5-8. 


\section{Pseudostaurosphaera? sp. aff. P. perelegans Krasheninnikov}

Pseudostaurosphaera perelegans Krasheninnikov, 1960, p. 276, pl. 1, fig. 6.

Pseudostaurosphaera? sp. aff. P. perelegans Krasheninnikov, Nishimura, 1992, p. 324, pl. 1, fig. 5; pl. 11, fig. 4.

\section{Pterocodon? ampla (Brandt)}

Theocyrtis ampla Brandt, in Wetzel 1935, p. 56, pl. 9, figs. 13-15.

Pterocodon? ampla (Brandt), Foreman, 1973, p. 438, pl. 5, figs. 3-5; Jackett et al., 2008, pl. 2, fig. 14.

\section{Pterocodon poculum Nishimura}

Plate 2, figures 37-39

Pterocodon poculum Nishimura, 1992, p. 350, pl. 8, figs. 1-3; pl. 13, fig. 13; Jackett et al., 2008, pl. 1, fig. 13.

\section{Saturnalis kennetti Dumitrica}

Plate 1, figures 5, 6

Saturnalis kennetti Dumitrica, 1985, p. 189, pl. 2, figs. 1, 2; pl. 3, fig. 15; Hollis, 1997, p. 42, pl. 4, fig. 14; 2002, pl. 1, fig. 17.

\section{Spongodiscus americanus Kozlova}

Plate 1, figures 39-41

Spongodiscus americanus Kozlova, Kozlova and Gorbovetz, 1966, p. 88, pl. 14, figs. 1, 2;

Sanfilippo and Riedel, 1973, p. 524, pl. 11, figs. 9-13; pl. 27, fig. 11; pl. 28, fig. 9; Jackett et al., 2008, pl. 4, fig. 9.

\section{Spongodiscus cruciferus (Clark and Campbell)}

Plate 2, figures $40-42$

Spongastericus cruciferus Clark and Campbell, 1942, p. 50, pl. 1, figs. 1-6, 8, 10, 11, 16-18.

Spongodiscus cruciferus (Clark and Campbell), Sanfilippo and Riedel, 1973, p. 524, pl. 11, figs. 14-17; pl. 28, figs. 10, 11; Jackett et al., 2008, pl. 4, fig. 8.

\section{Spongodiscus quartus bosoculus Sanfilippo and Riedel}

Plate 1, figures 42,43

Spongodiscus quartus bosoculus Sanfilippo and Riedel, 1973, p. 525, pl. 12, figs. 8-10; pl. 29, fig. 7; Nishimura, 1992, pl. 2, fig. 15.

\section{Spongurus bilobatus Clark and Campbell group}

Plate 1, figures 35-36

Spongurus bilobatus Clark and Campbell, 1942, p. 36, pl. 1, figs. 7-9.

Spongurus cf. bilobatus Clark and Campbell, Hollis, 1997, p. 47, pl. 7, figs. 15-18.

Spongurus bilobatus Clark and Campbell group, Hollis, 2002, p. 291, pl. 2, figs. 11-14. 


\section{Spongurus? irregularis Nishimura}

2 Plate 1, figures 29-31

3 Spongurus? irregularis Nishimura, 1992, pl. 2, figs. 7-9; pl. 12, figs. 3, 7; Jackett et al., 2008, pl. 4, figs. 6, 7 .

\section{Spongurus? regularis (Borisenko) group}

Plate 1 , figures 25-28

Cromyodruppa regularia Borisenko, 1958, p. 88, pl. 5, figs. 13, 14.

Spongurus? regularis (Borisenko) group, Nishimura, 1992, p. 328, pl. 2, figs. 11, 12; pl. 12, figs. 4-6.

\section{Stylosphaera minor Clark and Campbell}

Plate 1, figures 3,4

Stylosphaera minor Clark and Campbell, 1942, p. 27, pl. 5, figs. 1, 2, 12.

Amphisphaera minor (Clark and Campbell), Sanfilippo and Riedel, 1973, p. 486, pl. 1, figs. 1-5; pl. 22, fig. 4; Nishimura, 1987, pl. 1, fig. 5.

Stylosphaera minor Clark and Campbell, Hollis, 1997, p. 40, pl. 1, figs. 17, 18.

\section{Stylotrochus alveatus Sanfilippo and Riedel}

Plate 1, figures 46,47

Stylotrochus alveatus Sanfilippo and Riedel, 1973, p. 525, pl. 13, figs. 4, 5; pl. 30, figs. 3, 4.

\section{Stylotrochus nitidus Sanfilippo and Riedel}

Plate 1, figure 38

Stylotrochus nitidus Sanfilippo and Riedel, 1973, p. 525, pl. 13, figs. 9-14; pl. 30, figs. 7-10; Nishimura, 1987, pl. 1, fig. 12; Nishimura, 1992, pl. 2, fig. 1; pl. 12, fig. 8; Jackett et al., 2008, pl. 4, fig. 13.

\section{Thecosphaera Iarnacium Sanfilippo and Riedel}

Plate 1, figure 24

Thecosphaera larnacium Sanfilippo and Riedel, 1973, p. 521, pl. 3, figs. 4-6; pl. 25, figs. 13, 14; Jackett et al., 2008, pl. 3, figs 1, 2.

\section{Thecosphaerella ptomatus Sanfilippo and Riedel}

Plate 1 , figure 23

Thecosphaerella ptomatus Sanfilippo and Riedel, 1973, p. 521, pl. 3, figs. 14-18; pl. 26, fig. 2; Jackett et al., 2008, pl. 3, fig. 6.

\section{Thecosphaerella rotunda (Borisenko)}

Thecosphaera rotunda Borisenko, 1960, p. 222, pl. 1, fig. 3; pl. 3, figs. 2, 3.

Thecosphaerella rotunda (Borisenko), Sanfilippo and Riedel, 1973, pl. 3, figs. 7-11; pl. 26, fig. 3.

\section{Theocorys acroria Foreman}


Plate 2, figure 17

2 Theocorys acroria

3 pl. 2, fig. 24.

4

5

6

\section{Velicucullus? palaeocenica Nishimura}

Plate 1, figure 48

7 Velicucullus? palaeocenica Nishimura, 1992, p. 331, pl. 3, figs. 7, 9.

8

9 Xiphospira circularis (Clark and Campbell)

10 Plate 1 , figures 44,45

11 Porodiscus circularis Clark and Campbell, 1942, p. 42, pl. 2, figs. 2, 6, 10.

12 Xiphodictya amphixiphos (Clark and Campbell), 1942, p. 43, pl. 2, fig. 4.

13 Circodiscus circularis (Clark and Campbell), Jackett et al., 2008, pl. 4, figs. 10, 12.

14 Xiphospira circularis (Clark and Campbell), Sanfilippo and Riedel, 1973, p. 526, pl. 14, figs.

15 5-12: pl. 31, figs. 4-7; Nishimura, 1992, pl. 2, fig. 13; pl. 12, fig. 9.

16

\section{Acknowledgement}

18 Alan Baxter, Lily Chiu Mei Li, and Yuanyuan Sun (The University of Hong Kong) are thanked

19 for their technical help. ODP East Coast Repository (Lamont Doherty Earth Observatory) staff

20 Paula Weiss and Drew Patrick were very helpful during collection of the samples (in the

21 summer of 1997). We are very grateful to Christopher J. Hollis and Annika Sanfilippo for their 22 careful and constructive reviews. 


\section{References}

Ali, J.R. and Hailwood, E.A., 1998. Magnetostratigraphic (re)calibration of the Paleocene/Eocene boundary interval in Holes 550 and 549, Goban Spur, eastern North Atlantic. Earth and Planetary Science Letters, 161: 201-213.

Aubry, M.-P., Lucas, S.G. and Berggren, W.A. (Editors), 1998. Late Paleocene-Early Eocene Climatic and Biotic Events in the Marine and Terrestrial Records. Columbia University Press, New York, 513 pp.

Aubry, M.-P., Berggren, W.A., Stott, L. and Sinha, A., 1996. The upper Paleocene-lower Eocene stratigraphic record and the Paleocene-Eocene boundary carbon isotope excursion: implications for geochronology. In: R.W. O'B. Knox, R.M. Corfield and R.E. Dunay (Editors), Correlation of the Early Paleogene in Northwest Europe. Geological Society Special Publication, Volume 101, London, pp. 353-380.

Bijl, P.K., Schouten, S., Sluijs, A., Reichart, G.J., Zachos, J.C. and Brinkhuis, H., 2009. Early Palaeogene temperature evolution of the southwest Pacific Ocean. Nature, 461: 776-779.

Borisenko, N.N., 1958. Radiolyarii paleotsena zapadnoi Kubani (Paleocene Radiolaria of Western Kubanj). Trudy Vsesoyuznyi Neftegazovyi Nauchno-Issledovatelskii Institut (VNII), Krasnodarskii Filial, 17: 81-100.

Borisenko, N.N., 1960. Radiolyarii nizhnego i srednego eotsena zapadnoi Kubanj (The radiolarians of the Lower and Middle Eocene of Western Kubanj). Trudy Vsesoyuznyi Neftegazovyi Nauchno-Issledovatelskii Institut(VNII), Krasnodarskii Filial, 4: 219-232.

Brandt, R., 1935. Die Mikropalaeontologie des Heiligenhafener, Kieseltones (Ober-Eozan) Radiolarien; Systematik. In: E.O. Wetzel (Editor), Jahresbericht des Niedersachsischen geologischen Vereins, Hannover, Germany, vol. 27, pp. 48-59.

Campbell, A.S. and Clark, B.L., 1944. Radiolaria from Upper Cretaceous of Middle California. Geological Society of America Special Paper, 57: 1-61.

Clark, B.L. and Campbell, A.S., 1942. Eocene radiolarian faunas from the Monte Diablo area, California. Geological Society of America Special Paper, 39: 1-112.

Cramer, B.S., Wright, J.D., Kent, D.V. and Aubry, M.P., 2003. Orbital climate forcing of $\delta^{13} \mathrm{C}$ excursions in the late Paleocene-early Eocene (chrons C24n-C25n). Paleoceanography, 18: 1-25.

de Graciansky, P.C., Poag, C.W. and Foss, G., 1985. Initial Reports of the Deep Sea Drilling Project, Volume 80. U.S. Government Printing Office, Washington, DC., 1258 pp.

De Wever, P., Dumitrica, P., Caulet, J.P., Nigrini, C. and Caridroit, M., 2001. Radiolarians in the Sedimentary Record. Gordon and Breach Science Publishers, Amsterdam, 533 pp.

Dumitrica, P., 1985. Internal morphology of the Saturnalidae (Radiolaria): systematic and phylogenetic consequences. Revue de Micropaléontologie, 28(3): 181-196.

Ehrenberg, C.G., 1847. Uber die mikroskopischen kieselschaligen Polycystinen als machtige Gebirgsmasse von Barbados und uber das Verhaltniss deraus mehr als 300 neuen Arten bestehenden ganz eigenthumlichen Formengruppe jener Felsmasse zu den jetzt lebenden Thieren und zur Kreidebildung. Eine neue Anregung zur Erforschung des Erdlebens. Konigliche Preussische Akademie der Wissenschaften zu Berlin, Bericht, Jahre 1847: 40-60. 
Ehrenberg, C.G., 1873. Grossere Felsproben des Polycystinen-Mergels von Barbados mit weiteren Erlauterungen. Konigliche Preussische Akademie der Wissenschaften zu Berlin, Monatsberichte, Jahre 1873: 213-263.

Ehrenberg, C.G., 1875. Fortsetzung der mikrogeologischen Studien als Gesammt-Uebersicht der mikroskopischen Paläontologie gleichartig analysirter Gebirgsarten der Erde, mit specieller Rücksicht auf den Polycystinen-Mergel von Barbados. Königliche Akademie der Wissenschaften zu Berlin, Abhandlungen, Jahre, 1875: 1-225.

Foreman, H.P., 1973. Radiolaria of Leg 10 with systematics and ranges for the families Amphipyndacidae, Artostrobiidae, and Theoperidae. In: J.L. Worzel et al. (Editors), Initial Reports of the Deep Sea Drilling Project, Volume 10. U. S. Government Printing Office, Washington, D.C., pp. 407-474.

Gradstein, F.M., Ogg, J.G. and Smith, A.G. (Editors), 2005. A Geologic Time Scale 2004. Cambridge University Press, Cambridge, 589 pp.

Haeckel, E., 1887. Report on the Radiolaria collected by H.M.S. Challenger during the years 1873-1876. Report on the Scientific Results of the Voyage of the H.M.S. Challenger, Zoology, 18: 1-1803.

Hollis, C., 2002. Biostratigraphy and paleoceanographic significance of Paleocene radiolarians from offshore eastern New Zealand. Marine Micropaleontology, 46: 265-316.

Hollis, C., 2006. Radiolarian faunal turnover through the Paleocene-Eocene transition, Mead Stream, New Zealand. Eclogae Geologicae Helvetiae, 99: S79-S99.

Hollis, C.J., 1997. Cretaceous-Paleocene Radiolaria from eastern Marlborough, New Zealand. Institute of Geological \& Nuclear Sciences Monograph, 17: 1-152.

Hollis, C.J., Dickens, G.R., Field, B.D., Jones, C.M. and Strong, C.P., 2005. The Paleocene-Eocene transition at Mead Stream, New Zealand: a southern Pacific record of early Cenozoic global change. Palaeogeography Palaeoclimatology Palaeoecology, 215: 313-343.

Huber, M., Brinkhuis, H., Stickley, C.E., Doos, K., Sluijs, A., Warnaar, J., Schellenberg, S.A. and Williams, G.L., 2004. Eocene circulation of the Southern Ocean: Was Antarctica kept warm by subtropical waters? Paleoceanography, 19: PA4026.

Jackett, S.J., Baumgartner, P.O. and Bandini, A.N., 2008. A new low-latitude late Paleocene-early Eocene radiolarian biozonation based on unitary associations: applications for accreted terranes. Stratigraphy, 5(1): 39-62.

Kahn, A. and Aubry, M.P., 2004. Provincialism associated with the Paleocene/Eocene thermal maximum: temporal constraint. Marine Micropaleontology, 52: 117-131.

Kennett, J.P. and Stott, L.D., 1991. Abrupt deep-sea warming, palaeoceanographic changes and benthic extinctions at the end of the Paleocene. Nature, 353(6341): 225-229.

Knox, R.W.O'B., 1984. Nannoplankton zonation and the Palaeocene/Eocene boundary beds of NW Europe: an indirect correlation by means of volcanic ash layers. Journal of the Geological Society of London, 141: 993-999. Paleogene in northwest Europe. Geological Society Special Publication, Volume 101, London, $480 \mathrm{pp}$. 
Kozlova, G.E. and Gorbovetz, A.N., 1966. Radiolyarii verkhnemelovykh i verkhneeotsenovykh otlozhenii Zapadno-Sibirskoi nizmennosti (Radiolarians of the Upper Cretaceous and Upper Eocene deposits of the West Siberian Lowland). Trudy vsesoyuznogo neftyanogo nauchno-issledovatelskogo geologorazvedochnogo instituta (VNIGRI) (Proceedings of the All Union Petroleum Scientific Research Institute for Geological Survey (VNIGRI)), 248: 1-159.

Krasheninnikov, V.A., 1960. Nekotorye Radiolyarii Nizhnego i Srednego Eotsena Zapadnogo Predkavkazya (Some radiolarians of the lower and middle Eocene of the western Caucasus). Mineralogicko-Geologicka i Okhrana Nedr SSSR Vsesoyuznogo Nauchno-Issledovatelskogo Geologorazved Neftyanogo Instituta, 16: 271-308.

Nigrini, C. and Sanfilippo, A., 2000. Paleogene radiolarians from sites 998, 999, and 1001 in the Caribbean. In: R.M. Leckie, H. Sigurdsson, G.D. Acton and G. Draper (Editors), Proceedings of the Ocean Drilling Program, Scientific Results, Volume 165. Texas A \& M University, Texas, pp. 57-81.

Nishimura, A., 1987. Cenozoic Radiolaria in the western North Atlantic, Site 603, Leg 93 of the Deep Sea Drilling Project. In: J.E. Van Hinte and S.W. Wise Jr. et al. (Editors), Initial Reports of the Deep Sea Drilling Project, Volume 93. U. S. Government Printing Office, Washington, D.C., pp. 713-737.

Nishimura, A., 1992. Paleocene radiolarian biostratigraphy in the northwest Atlantic at Site 384, Leg 43, of the Deep Sea Drilling Project. Micropaleontology, 38: 317-362.

O'Connor, B., 2001. Buryella (Radiolaria, Artostrobiidae) from DSDP Site 208 and ODP Site 1121. Micropaleontology, 47: 1-22.

Riedel, W.R. and Sanfilippo, A., 1970. Radiolaria, Leg 4, Deep Sea Drilling Project. In: R.G. Bader and R.D. Gerard et al. (Editors), Initial Reports of the Deep Sea Drilling Project, Volume 4. U. S. Government Printing Office, Washington, D.C., pp. 503-575.

Riedel, W.R. and Sanfilippo, A., 1971. Cenozoic Radiolaria from the western tropical Pacific, Leg 7. In: E.L. Winterer and W.R. Riedel et al. (Editors), Initial Reports of the Deep Sea Drilling Project, Volume 7. U. S. Government Printing Office, Washington, D.C., pp. 1529-1672.

Röhl, U., Bralower, T.J., Norris, R.D. and Wefer, G., 2000. New chronology for the Late Paleocene Thermal Maximum and its environmental implications. Geology, 28(10): 927-930.

Röhl, U., Westerhold, T., Bralower, T.J. and Zachos, J.C., 2007. On the duration of the Paleocene-Eocene thermal maximum (PETM). Geochemistry Geophysics Geosystems, 8: Q12002.

Sanfilippo, A. and Blome, C.D., 2001. Biostratigraphic implications of mid-latitude Palaeocene-Eocene radiolarian faunas from Hole 1051A, ODP Leg 171B, Blake Nose, western North Atlantic. In: D. Kroon, R.D. Norris and A. Klaus (Editors), Western North Atlantic Palaeogene and Cretaceous palaeoceanography. Geological Society Special Publication, Volume 183, London, pp. 185-224.

Sanfilippo, A. and Hull, D.M., 1999. Upper Paleocene-lower Eocene radiolarian biostratigraphy of the San Francisco de Paula Section, Western Cuba: regional and global comparisons. Micropaleontology, 45: 57-82. 
Sanfilippo, A. and Nigrini, C., 1998. Upper Paleocene-lower Eocene deep-sea radiolarian stratigraphy and the Paleocene/ Eocene series boundary. In: M.-P. Aubry, S.G. Lucas and W.A. Berggren (Editors), Late Paleocene-Early Eocene Climatic and Biotic Events in the Marine and Terrestrial Records. Columbia University Press, New York, pp. 244-276.

Sanfilippo, A. and Riedel, W.R., 1973. Cenozoic Radiolaria (exclusive of theoperids, artostrobiids and amphipyndacids) from the Gulf of Mexico, DSDP Leg 10. In: J.L. Worzel et al. (Editors), Initial Reports of the Deep Sea Drilling Project, Volume 10. U. S. Government Printing Office, Washington, D.C., pp. 475-611.

Sanfilippo, A., Westberg-Smith, M.J. and Riedel, W.R., 1985. Cenozoic Radiolaria. In: H.M. Bolli, J.B. Saunders and K. Perch-Nielsen (Editors), Plankton Stratigraphy. Cambridge University Press, Cambridge, pp. 631-712.

Sluijs, A. et al., 2006. Subtropical arctic ocean temperatures during the Palaeocene/Eocene thermal maximum. Nature, 441(7093): 610-613.

Sluijs, A., Bowen, G.J., Brinkhuis, H., Lourens, L.J. and Thomas, E., 2007. The Palaeocene-Eocene Thermal Maximum super greenhouse: biotic and geochemical signatures, age models and mechanisms of global change. In: M. Williams, A.M. Haywood, F.J. Gregory and D.N. Schmidt (Editors), Deep-Time Perspectives on Climate Change: Marrying the Signal from Computer Models and Biological Proxies. The Micropalaeontological Society, Special Publications. The Geological Society, London, pp. 323-349.

Squinabol, S., 1904. Radiolarie cretacee degli Euganei. Atti e memorie dell'Accademia di scienze, lettere ed arti. Padova, New Series, 20: 171-244.

Thomas, D.J. and Bralower, T.J., 2005. Sedimentary trace element constraints on the role of North Atlantic Igneous Province volcanism in late Paleocene-early Eocene environmental change. Marine Geology, 217: 233-254.

Tripati, A., Zachos, J.C., Marincovich, L. and Bice, K.L., 2001. Late Paleocene Arctic coastal climate inferred from molluscan stable and radiogenic isotope ratios. Palaeogeography Palaeoclimatology Palaeoecology. 170: 101-113.

Weijers, J.W.H., Schouten, S., Sluijs, A., Brinkhuis, H. and Damste, J.S.S., 2007. Warm arctic continents during the Palaeocene-Eocene thermal maximum. Earth and Planetary Science Letters, 261: 230-238.

Wing, S.L., Bao, H. and Koch, P.L., 2000. An early Eocene cool period? Evidence for continental cooling during the warmest part of the Cenozoic. In: B.T. Huber, K.G. MacLeod and Wing, S.L. (Editors), Warm Climates in Earth History. Cambridge University Press, Cambridge, pp. 197-237. Globally Warm Climates in the Early Paleogene. Geological Society of America, Boulder, Colorado., 614 pp. 


\section{Table Captions}

2 1. Stratigraphic depth (mbsf) of the biostratigraphic, chemostratigraphic, and

3 magnetostratigraphic tie-points used to construct the age model.

4 2. Abundance, preservation, and occurrence of radiolarians in the upper Paleocene-lower $5 \quad$ Eocene in DSDP Site 549.

6 3. Abundance, preservation, and occurrence of radiolarians in the upper Paleocene-lower 7 Eocene in DSDP Site 550. 


\section{Figure Captions}

2 1. Modern map s

map showing the location of DSDP Sites 549 and 550, Goban Spur.

3 2. Stratigraphic ranges of radiolarian species in DSDP Site 549.

4 3. Paleogeographic reconstruction of the late Paleocene ( $\sim 56 \mathrm{Ma})$ showing the location of 5 DSDP Leg 80 and Mead Stream (generated from http://www.serg.unicam.it/Reconstructions.htm). 


\section{Plates}

2 Plate 1

3 All illustrations are scanning electron micrographs of upper Paleocene radiolarians from

4 DSDP Site 549. All illustrated specimens can be located with SEM stub number, followed by

5 specimen number on the stub. All scale bars equal $100 \mu \mathrm{m}$.

6 1. Axoprunum pierinae (Clark and Campbell). 549-17-1-82-A, 3.

7 2. Axoprunum pierinae (Clark and Campbell). 549-17-2-99, 110.

8 3. Stylosphaera minor Clark and Campbell. 549-17-2-99, 50.

9 4. Stylosphaera minor Clark and Campbell. 549-18-1-43, 3.

10 5. Saturnalis kennetti Dumitrica. 549-17-2-99, 55.

11 6. Saturnalis kennetti Dumitrica. 549-19-1-64, 4.

12 7. Amphisphaera coronata (Ehrenberg). 549-17-3-79-A, 87

13 8. Amphisphaera macrosphaera (Nishimura). 549-18-2-116, 51.

14 9. Amphisphaera goruna (Sanfilippo and Riedel). 549-18-2-116, 77.

15 10. Lithomespilus coronatus Squinabol. 549-17-3-79-A, 51.

16 11. Lithomespilus coronatus Squinabol. 549-18-2-116, 45.

17 12. Lithomespilus coronatus Squinabol. 549-17-6-138, 12.

18 13. Lithomespilus coronatus Squinabol. 549-17-3-79-A, 52.

19 14. Lithomespilus coronatus Squinabol. 549-17-3-79-A, 17.

20 15. Hexacontium palaeocenicum Sanfilippo and Riedel. 549-19-4-112, 85.

21 16. Hexacontium palaeocenicum Sanfilippo and Riedel. 549-17-3-79-A, 31.

22 17. Hexacontium palaeocenicum Sanfilippo and Riedel. 549-17-3-79-A, 22.

23 18. Hexacontium palaeocenicum Sanfilippo and Riedel. 549-18-2-116, 75.

24 19. Hexacontium sp.. 549-17-1-82-B, 2.

25 20. Hexacontium sp.. 549-17-2-99, 41.

26 21. Hexacontium sp.. 549-17-3-79-B, 1.

27 22. Carposphaera subbotinae (Borisenko). 549-17-2-99, 76.

28 23. Thecosphaerella ptomatus Sanfilippo and Riedel. 549-17-2-99, 88.

29 24. Thecosphaera larnacium Sanfilippo and Riedel. 549-17-2-99, 1.

30 25. Spongurus? regularis (Borisenko) group. 549-17-3-79-A, 9.

31 26. Spongurus? regularis (Borisenko) group. 549-17-6-138, 47.

32 27. Spongurus? regularis (Borisenko) group. 549-17-3-79-A, 28.

33 28. Spongurus? regularis (Borisenko) group. 549-17-3-79-A, 50.

34 29. Spongurus? irregularis Nishimura. 549-19-4-112, 60.

35 30. Spongurus? irregularis Nishimura. 549-17-6-138, 42.

36 31. Spongurus? irregularis Nishimura. 549-17-3-79-A, 14.

37 32. Amphicraspedum prolixum Sanfilippo and Riedel group. 549-17-6-138, 54.

38 33. Amphicraspedum prolixum Sanfilippo and Riedel group. 549-17-2-99, 116.

39 34. Amphicraspedum murrayanum Haeckel. 549-17-3-79-A, 1.

40 35. Spongurus bilobatus Clark and Campbell. 549-18-2-116, 92.

41 36. Spongurus bilobatus Clark and Campbell. 549-17-6-138, 51.

42 37. Prunopyle adelstoma Kozlova and Gobovets. 549-17-2-99, 70.

43 38. Stylotrochus nitidus Sanfilippo and Riedel. 549-17-3-79-A, 7.

44 39. Spongodiscus americanus Kozlova. 549-17-2-99, 89. 
40. Spongodiscus americanus Kozlova. 549-17-3-79-B, 56.

2 41. Spongodiscus americanus Kozlova. 549-17-2-99, 111.

3 42. Spongodiscus quartus bosoculus Sanfilippo and Riedel. 549-17-3-79-B, 21.

4 43. Spongodiscus quartus bosoculus Sanfilippo and Riedel. 549-17-3-79-B, 22.

5 44. Xiphospira circularis (Clark and Campbell). 549-17-3-79-B, 28.

45. Xiphospira circularis (Clark and Campbell). 549-19-1-64, 11.

46. Stylotrochus alveatus Sanfilippo and Riedel. 549-17-2-99, 34.

8 47. Stylotrochus alveatus Sanfilippo and Riedel. 549-17-3-79-B, 19.

9 48. Velicucullus? palaeocenica Nishimura. 549-17-3-79-B, 58.

49. Cassideus mariae Nishimura. 549-17-6-138, 50.

Plate 2

All illustrations are scanning electron micrographs of upper Paleocene radiolarians from DSDP Site 549. All illustrated specimens can be located with SEM stub number, followed by specimen number on the stub. All scale bars equal $100 \mu \mathrm{m}$.

1. Cassideus mariae Nishimura. 549-17-1-82-B, 18.

3. Cassideus mariae Nishimura. 549-17-2-99, 17

19 4. Diplocyclas pseudobicorona teres Nishimura. 549-17-2-99, 22.

20 5. Diplocyclas pseudobicorona teres Nishimura. 549-17-2-99, 73.

6. Diplocyclas pseudobicorona pseudobicorona Nishirnura. 549-17-2-99, 18.

22 7. Diplocyclas pseudobicorona pseudobicorona Nishirnura. 549-17-2-99, 19.

23 8. Diplocyclas pseudobicorona pseudobicorona Nishirnura. 549-17-2-99, 20.

24 9. Diplocyclas pseudobicorona pseudobicorona Nishirnura. 549-17-2-99, 104.

10. Diplocyclas pseudobicorona pseudobicorona Nishirnura. 549-19-1-64, 26.

11. Bathropyramis magnifica (Clark and Campbell). 549-17-3-79-A, 35.

12. Buryella pentadica Foreman. 549-19-1-64, 43.

13. Buryella tetradica tetradica Foreman. 549-17-3-79-A, 6.

14. Podocyrtis sp. aff. P. papalis Ehrenberg. 549-17-6-138, 49.

15. Phormocyrtis striata exquisita (Kozlova). 549-17-3-79-A, 47.

16. Phormocyrtis striata exquisita (Kozlova). 549-17-3-79-A, 80.

17. Theocorys acroria Foreman. 549-17-2-99, 109.

18. Dictyocephalus middouri s.I. Nishimura. 549-17-2-99, 14.

19. Dictyocephalus middouri s.I. Nishimura. 549-17-2-99, 15.

20. Dictyocephalus middouri s.I. Nishimura. 549-17-3-79-B, 32.

21. Lychnocanium carinatum Ehrenberg. 549-18-2-116, 76.

22. Lychnocanium carinatum Ehrenberg. 549-18-2-116, 12.

23. Lychnocanoma auxilla Foreman. 549-17-2-99, 8.

24. Lychnocanoma auxilla Foreman. 549-17-2-99, 9.

25. Lychnocanoma auxilla Foreman. 549-17-2-99, 10.

26. Lychnocanoma auxilla Foreman. 549-17-2-99, 95.

27. Lychnocanoma auxilla Foreman. 549-17-2-99, 96.

28. Lychnocanoma auxilla Foreman. 549-17-3-79-B, 54.

29. Lychnocanoma auxilla Foreman. 549-17-2-99, 114. 

1 30. Lamptonium pennatum Foreman. 549-17-3-79-B, 52.
2 31. Lamptonium pennatum Foreman. 549-17-2-99, 4.
3 32. Bekoma bidartensis Riedel and Sanfilippo. 549-17-3-79-A, 91.
4 33. Dendrospyris golli Nishimura. 549-17-1-82-A, 11.
5 34. Dendrospyris golli Nishimura. 549-17-2-99, 106.
6 35. Dorcadospyris platyacantha (Ehrenberg) group. 549-17-6-138, 28.
7 36. Dorcadospyris platyacantha (Ehrenberg) group. 549-18-2-116, 26.
8 37. Pterocodon poculum Nishimura. 549-17-3-79-A, 69.
9 38. Pterocodon poculum Nishimura. 549-17-3-79-A, 58.
10 39. Pterocodon poculum Nishimura. 549-18-2-116, 17.
11 40. Spongodiscus cruciferus (Clark and Campbell). 549-17-2-99, 74.
12 41. Spongodiscus cruciferus (Clark and Campbell). 549-17-2-99, 75.
13 42. Spongodiscus cruciferus (Clark and Campbell). 549-17-3-79-B, 59. 


\begin{tabular}{|c|c|c|c|}
\hline \multicolumn{4}{|c|}{ Site 549 } \\
\hline Datum & Age (Ma) & Depth (mbsf) & References \\
\hline C22n/C22r & 49.427 & 276.61 & de Graciansky et al., 1985 \\
C22r/C23n & 50.73 & 286.52 & de Graciansky et al., 1985 \\
C24n.1r/2n & 53.116 & 304.08 & Ali and Hailwood, 1998 \\
C24n.2n/2r & 53.167 & 305.21 & Ali and Hailwood, 1998 \\
C24n.2r/3n & 53.286 & 307.62 & Ali and Hailwood, 1998 \\
C24n.3n/3r & 53.808 & 318 & Ali and Hailwood, 1998 \\
NP11/10 & 54.23 & 335.16 & Knox et al., 1996 \\
HO Fasciculithus tympaniformis & 55.63 & 335.55 & Knox et al., 1996 \\
CIE base & 55.8 & 339.68 & Thomas and Bralower, 2005 \\
NP9/8 & 56.5 & 352.3 & de Graciansky et al., 1985 \\
C25r/C26n & 58.379 & 374.12 & de Graciansky et al., 1985 \\
\hline \multicolumn{3}{|c|}{ Site 550 } & References \\
\hline Datum & Age (Ma) & Depth (mbsf) & Cramer et al., 2003 \\
\hline C23r/C24n & 52.648 & 342.07 & Cramer et al., 2003 \\
ETM 2 base & 53.55 & 362.74 & Knox, 1984 \\
Base of Ash -17 & 55.07 & 400.04 & Cramer et al., 2003 \\
CIE base & 55.8 & 409.79 & Cramer et al., 2003 \\
C24r/C25n & 56.665 & 422.12 & Cramer et al., 2003 \\
C25n/C25r & 57.18 & 425.09 & \\
\hline \multicolumn{3}{|c}{}
\end{tabular}




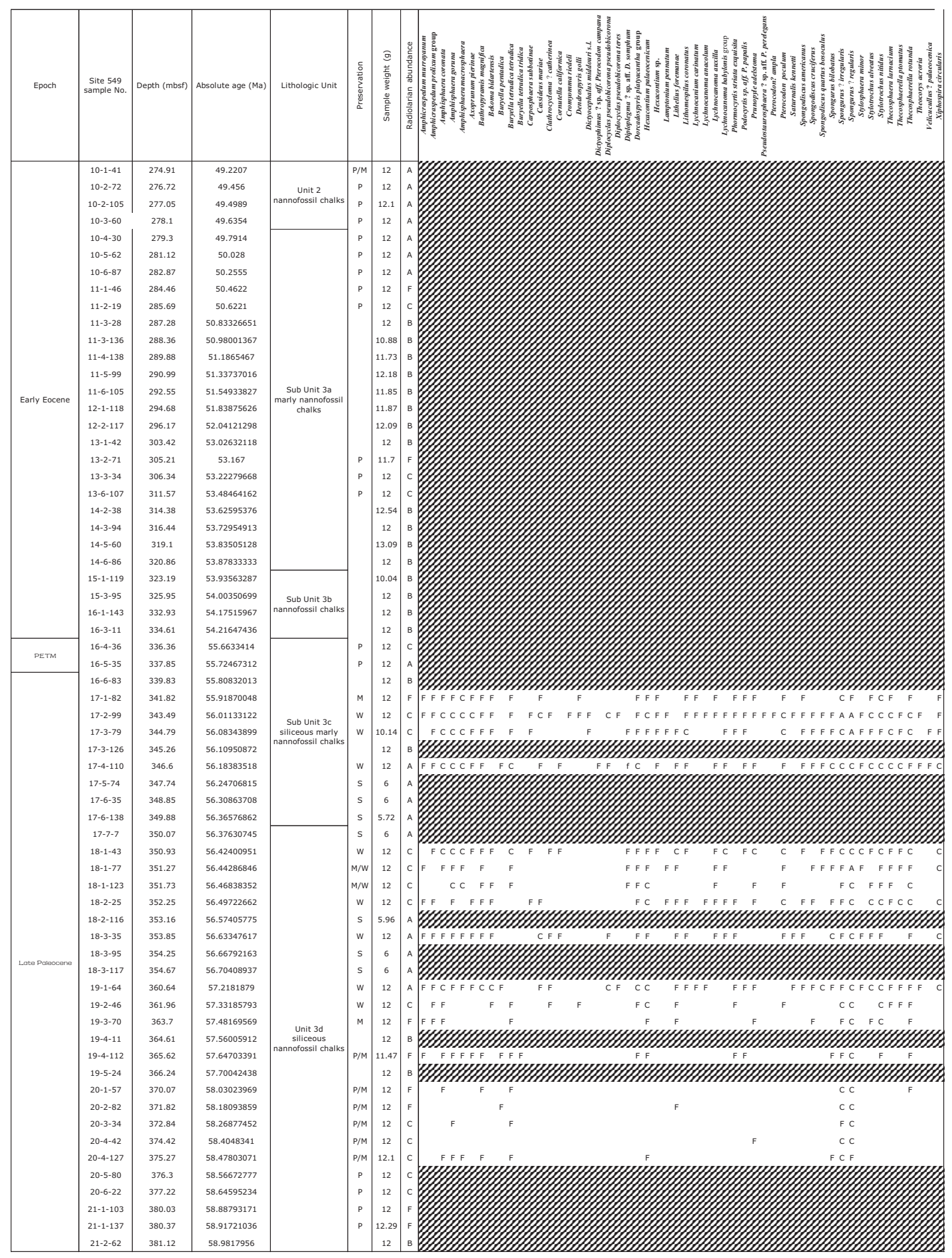




\section{Table 3}

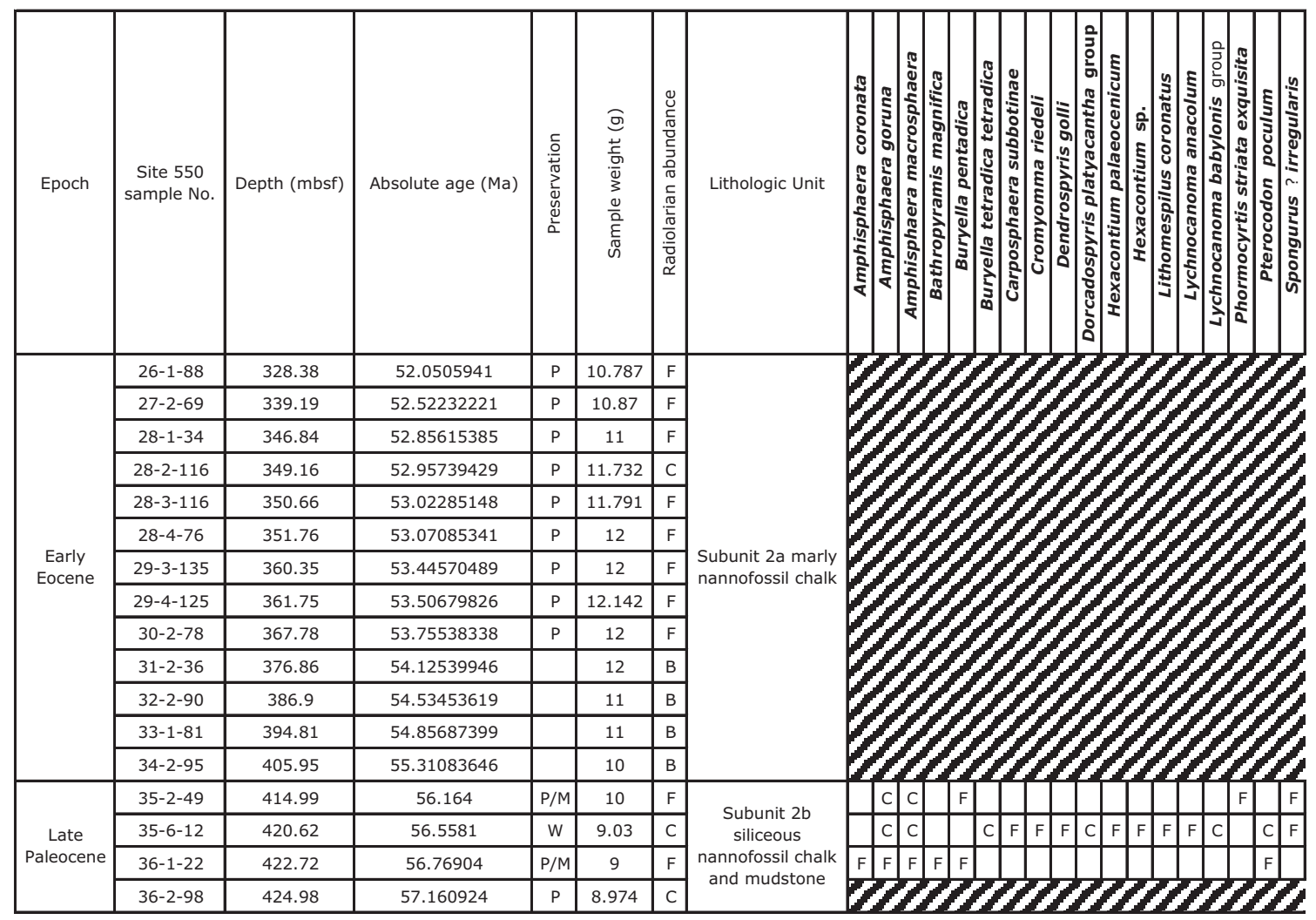




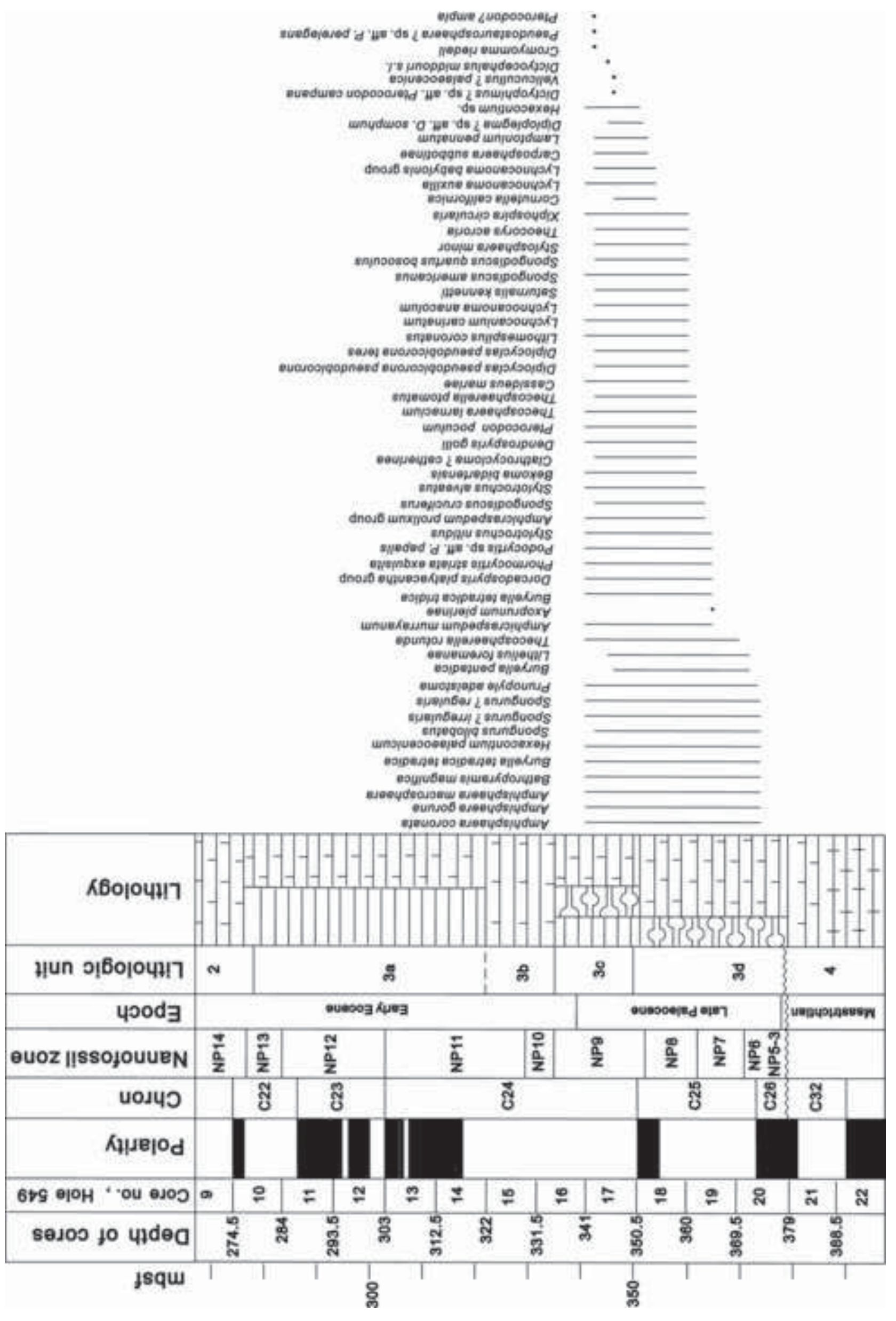




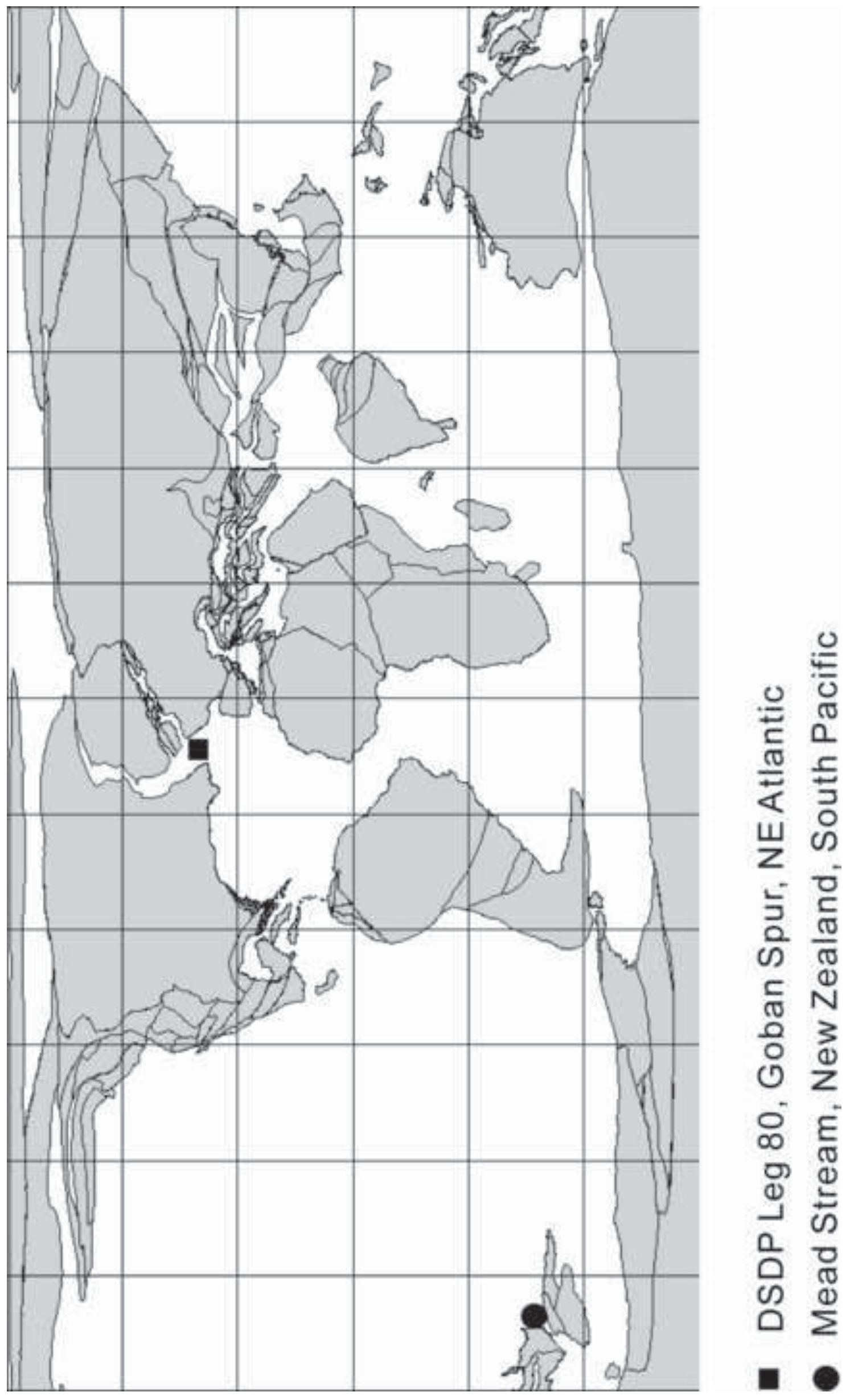

은 


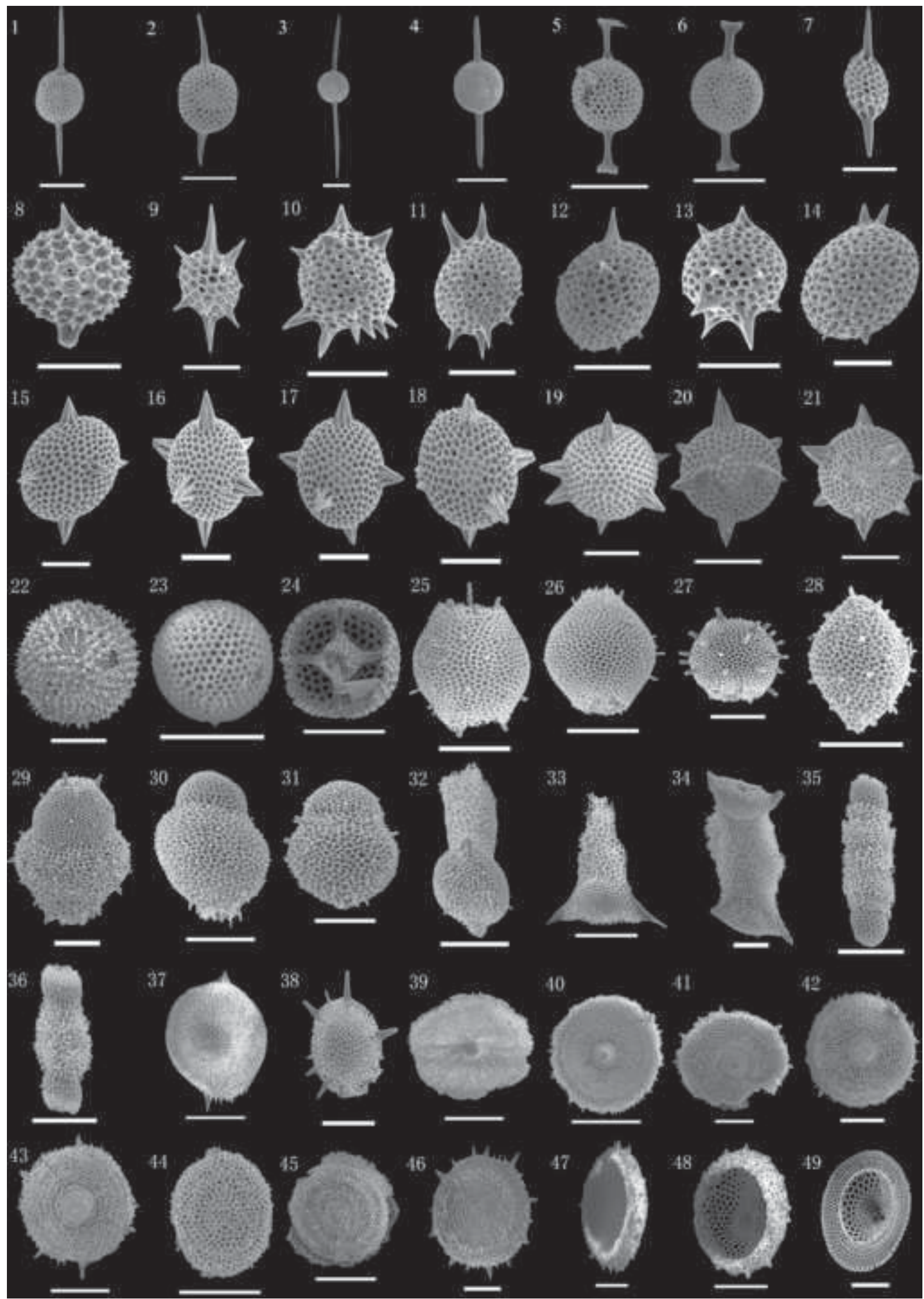




\section{Plate 2}

Click here to download high resolution image

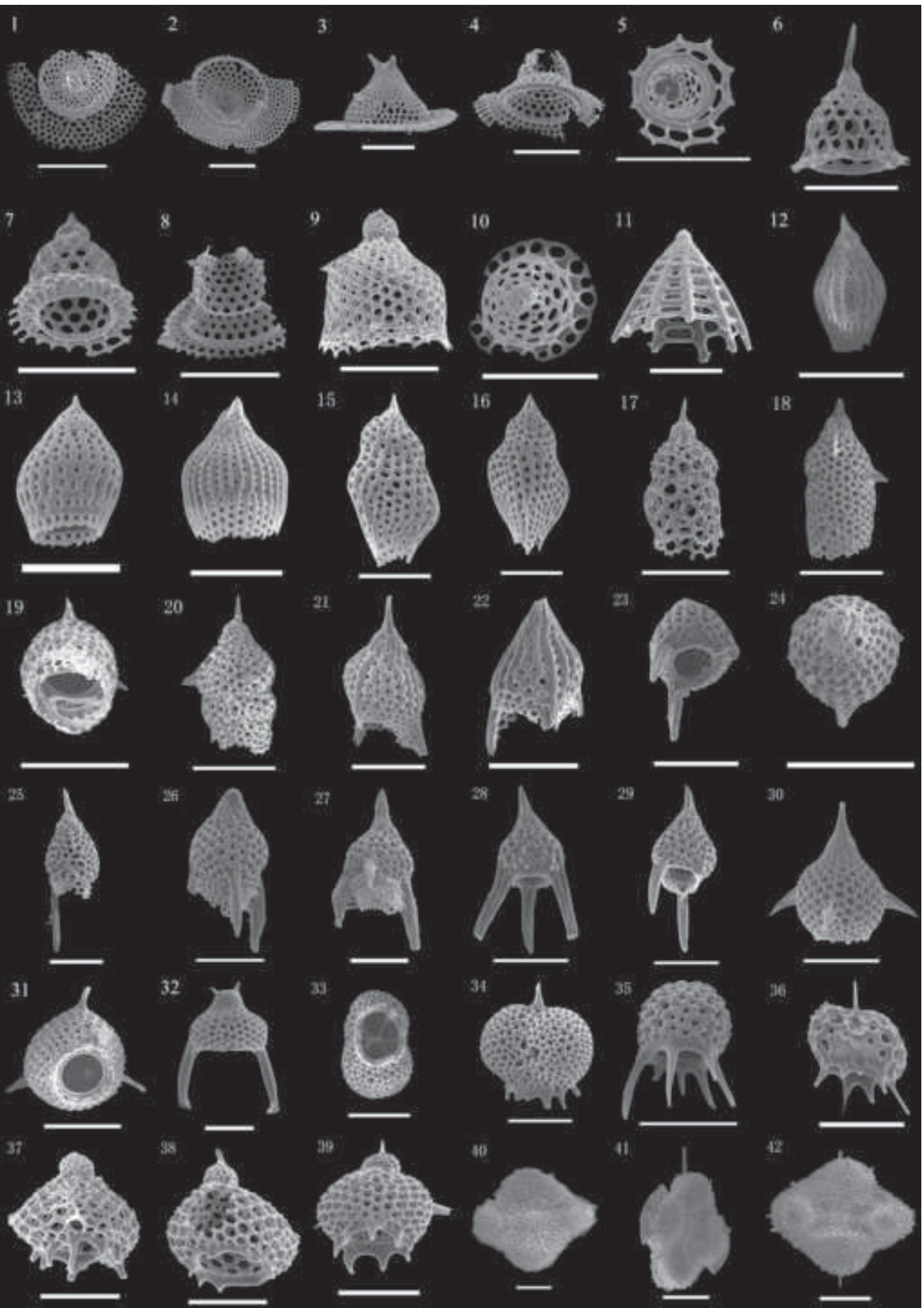

